\title{
Winter Food Resources and Food Preferences of Red Deer in Carpathian Forests
}

\author{
Grzegorz JAMROZY
}

\begin{abstract}
Jamrozy G., 1980: Winter food resounces and food preferences of red deer in Carpathian forests. Acta theriol., 25, 17: 221-238 [With 4 Tables \& 9 Figs.].

The studies were carried out in lower montane belt forests in three locations situated in the western, central, and eastern part of the Polish Carpathians. In the association Fagetum carpaticum the most abundant resources of browse were in initial stands, those with a low density and in regeneration, while least abundant ones - in middle-aged stands with a high density. Biomass of bark, which may constitute deer food, calculated for the Krynica region was on average by five times greater than browse resources. Three main forest-forming species, namely fir, spruce and beech, and from among shrubs - sallow, prevailed both in browse and in bark biomass. Trees and shrubs provided the bulk of the winter diet of red deer, first of all in the form of browse and then - bark. Herb layer vegetation - dwarf-shrubs and deciduous plants - is to a serious extent excluded from deer diet by a thick snow cover prevailing generally in mountains. Deer consumed shoots of 36 and bark of 27 species of trees and shrubs. The proportion of fir in diet was dominant (about $1 / 3$ of the entire diet) and that of sallow was very high. Indices of food preferences were determined in this paper for more frequent woody species.

[Dept. Forest Protection, College of Agriculture, Al. Mickiewicza 21, 31-120 Kraków, Poland].
\end{abstract}

\section{INTRODUCTION}

Studies on the ecology of the red deer (Cervus elaphus Lin n a us, 1758) carried out recently (D z ięciołowski, 1969; B obek et al., 1974; Dzięciołowski et al., 1975; Ahlén, 1965a,b and 1975, and others) characterized their food habits and potential resources of food available in lowland forests. There were no studies with us, however, in mountain forests, which constitute more than $10 \%$ of the forest area in Poland.

The size and quality of plant food resources constitute one of fundamental factors conditioning deer management (D z i ęc i o ł o w s k i, 1974). The size of food resources is particularly important for these animals during winter, when as a result of remarkable decline in food quantity and quality, this factor acquires the role of an ecological 
minimum and food requirements of deer usually surpass the available food in respect to amount and quality ( $\mathrm{K}$ le in, 1965). Composition of red deer diet varies during individual seasons of year in relation to food resources available (D z i ęc i o łowski, 1969). During vegetation season, when available food occurs in excess, deer diet better reflects their requirements and preferences, while during winter deer are forced to utilize considerably reduced food resources. Knowledge of food preferences of red deer on the background of natural food resources available in winter is important for the proper management of their populations and provides a fundamental determinant of the food-carrying capacity of range ( $\mathrm{S} \mathrm{h}$ a f e r, 1965).

The purpose of this work was to learn about (1) available resources of natural food for red deer during winter and (2) winter diet of red deer in Polish Carpathian forests. Studies on food resources dealt first of all with the main winter food of red deer in mountains, i.e. browse. Comparing proportions of woody plants consumed in the potential food reserve and in actual diet of deer made it possible to determine their food preferences.

\section{CHARACTERISTICS OF STUDY AREAS}

Studies on the trophic situation of red deer were carried out in lower mountain belt forests of the Polish part of Carpathian mountain range, in three study

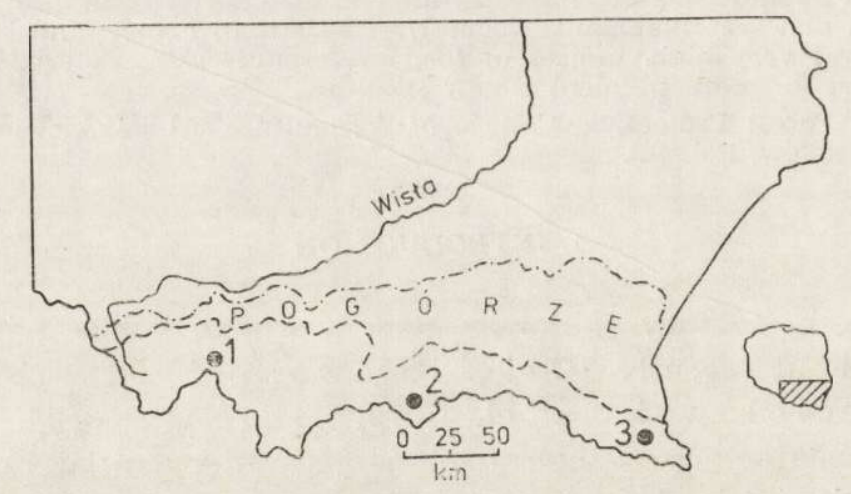

Fig. 1. Distribution of study areas within the Polish part of the Carpathian Mts range.

Regions: 1 - Babia Góra, 2-Krynica, and 3-Bieszczady

areas: (1) the Babia Góra National Park and the Sucha Beskidzka forest district in the region of Beskid Żywiecki, at northern foothills of the Babia Góra $\left(49^{\circ} 34^{\prime}-49^{\circ} 36^{\prime} \mathrm{N}, 19^{\circ} 27^{\prime}-19^{\circ} 35^{\prime} \mathrm{E}\right)$, (2) the Experimental Forests, Agricultural College at Krynica (region of the Beskid Sącecki - $49^{\circ} 23^{\prime}-49^{\circ} 27^{\prime} \mathrm{N}, 20^{\circ} 53^{\prime}-21^{\circ} 01^{\prime} \mathrm{E}$ ), and (3) Stuposiany (foothills of the Polonina Caryńska) and Lutowiska (southern 
part of the Otryt range) forest districts in Bieszczady Mts. $\left(49^{\circ} 06^{\prime}-49^{\circ} 15^{\prime} \mathrm{N}\right.$, $22^{\circ} 33^{\prime}-22^{\circ} 42^{\prime}$ E) (Fig. 1).

The association of Carpathian beechwood - Fagetum carpaticum is the dominant plant association occuring under natural conditions in the lower mountain belt. It occupied almost entire forest area in the region of Krynica and in Bieszczady Mts., while at Babia Góra in the lower mountain belt mixed deciduous forest (Abieti-Piceetum montanum) was also important. Poorer sites (of the mixed coniferous forest Babia Góra, while mixed deciduous forest in the remaining areas) occurred mainly in upper elevations situated beyond the zone of the winter mainstays of red deer and were not included in direct field work. Great stratification of stands in respect to age, making frequently impossible their division into age stages, was a characteristic feature of the forest tracts studied.

Red deer was common in study areas and finding its tracks in snow or signs of feeding did not pose any greater difficulties; roe deer was less numerous. Wild boar occurred everywhere and in vicinity of study areas in Bieszczady also European bison.

\section{PROCEDURE AND MATERIAL}

As it results from recent research browse from trees, shrubs, and dwarf-shrubs, bark from certain woody species, and herb layer plants constitute major winter food of red deer. The present work was restricted to the examination of potential resources of browse. The proportion of bark biomass available for consumption has been measured more at random, while the appraisal of resources from the remaining groups of plant food, which under mountain conditions are protected during a considerable portion of winter against intensive feeding, was omitted.

The analysis of supply of tree and shrub twigs was performed in the dominant association of Fagetum carpaticum. Forest biotope was divided according to developmental phases of a stand, its structure and density, and first of all according to the quantity and quality of understorey and regeneration under canopy. With the aid of the indices mentioned forest areas studied were classed into patches possibly homogeneous in respect to feeding conditions. These patches were named categories of forest biotope. Forest survey data were utilized for the delineation of these areas.

Following categories were identified: (a) initial stands dominated by young generation of trees and shrubs without an upper storey or with the upper storey with density below 0.3 ; (b) stands with a low density and in regeneration class - predominantly strongly thinned timber stands, but also stands in middle age-classes with a very low density and an abundant regeneration under canopy; (c) timber stands, in which some loosening of density renders possible the appearance of the lower storey; (d) highly dense stands - with complete or almost complete lack of understorey; (e) forecrop stands - usually about 30 years old, which dominated farm abandoned lands and have shade tolerant trees and shrubs under their canopy as a result of planting or self-sowing; (f) afforested meadows - also a category formed on farm abandoned lands, but without a contiguous tree storey.

Harvest plot method consisting in cutting current growths considered the potential deer food within the zone up to the height of $200 \mathrm{~cm}$ above ground or snow level, was used in the determination of browse resources. Circular sample plots were used, because as noted by De Vos \& Mos by (1969) they are most advantageous due to the lowest number of boundary decisions in relation to their 
area. Within each category of forest biotope at least 30 sample plots with the area of $20 \mathrm{~m}^{2}$ have been established. It was only on encroached by forest meadows in Bieszczady, which characterized themselves by a scattered and uneven occurrence of the biomass of trees and shrubs, where the area of plots amounted to $100 \mathrm{~m}^{2}$. Plots have been located along predetermined transects in several various places within individual category, at $50 \mathrm{~m}$ intervals. Twigs collected from each plot were segregated according to species and then dried during 48 hours at $70^{\circ} \mathrm{C}$ and weighed with the accuracy to $0.1 \mathrm{~g}$.

The material collected comes from 650 sample plots; 180 in forests of the Babia Góra, range, 290 from the vicinity of Krynica, and 180 from the Bieszczady Mts.

Biomass (reserve) of browse calculated for all habitat categories was subjected to an analysis of variance in order to determine whether differences between categories are statistically significant and afterwards to a new multiple range test (O k t a ba, 1977).

Tentative measurement of the biomass of bark constituting a potential food of red deer, i.e. unsuberized bark, which has been actually consumed from plants of preferred species, was taken on 75 sample plots in vicinity of Krynica (15 plots in each of five habitat categories). To this end diameter of shoot (stem) had been measured halfway the feeding zone, and thus at the height of $1 \mathrm{~m}$ above ground level, and when the specimen measured was lower - in half of its height. Such a measurement enabled the calculation of perimeter and afterwards - the appraisal of bark surface accessible for feeding (while multiplying the perimeter by the height of a feeding zone). In turn, while using conversion factors (dry matters of $1 \mathrm{~cm}^{2}$ of various thickness bark of individual woody species), determined on the basis of bark samples collected on the occasion of studies on red deer diet, the dry matter of bark available to red deer on the areas studied was calculated.

Studies on the winter diet of red deer were carried out with the aid of the method of tracking in snow after feeding deer. A similar procedure was used by Ahlén (1965b) and Dzięciolowski (1969), who counted all sings of feeding in the form of so-called bites. In the present studies author's own procedure was used. Its purpose was to measure feeding in absolute volume units.

While following the fresh track of red deer or a small herd of them author measured diameters of all shoots browsed, as well as area and thickness of the bark stripped. At the same time undamaged shoots with diameter identical to that of browsed shoots and bark samples with definite area and thickness were consumed species. The sample with bulk possibly identical to the consumed one $10 \%$ of the number of shoots browsed or bark area stripped for most frequently utilized species to $100 \%$ of the number of shoots and bark areas for rarely consumed species. The sample with bulk possibly identical to the consumed one has been taken on each occasion for the remaining kinds of food (herb layer plants, mosses, etc.). The length of route travelled was measured and the stands penetrated successively were described with particular reference to their understorey, in the course of tracking.

Plant samples taken have been segregated according to kind of food and plant species, and then dried and weighed. Afterwards mean dry matter of one browsed twig of all species consumed and of $1 \mathrm{~cm}^{2}$ of bark with definite thickness in species consumed were calculated for each study area. This rendered possible a simple calculation of the weight of identified components of red deer food consumed in the habitats studied. 
Analysis of red deer feeding was carried out altogether along tracks with the total length of $145,080 \mathrm{~m}(51,180 \mathrm{~m}$ in Babia Bóra region, $56,250 \mathrm{~m}$ in the Krynica forests, and $37,650 \mathrm{~m}$ in Bieszczady).

Field work was done in the Krynica forests during three winter seasons (1975/76 until 1977/78), while in the Babia Góra range and in Bieszczady - during two winters (1976/77 and 1977/78).

\section{RESULTS}

\subsection{Reserve and Species Composition of Browse}

The greatest reserves of browse were in initial stands, stands with a loose density and in the regeneration class, considerably smaller were in timber stands, forecrop stands, and afforested meadows in Bieszczady, while decidedly lowest ones - in stands with a high density (Table 1).

Table 1

Browse reserve (in $\mathrm{g}$ of dry matter $/ \mathrm{m}^{2}$ ) in identified classes of forest habitat.

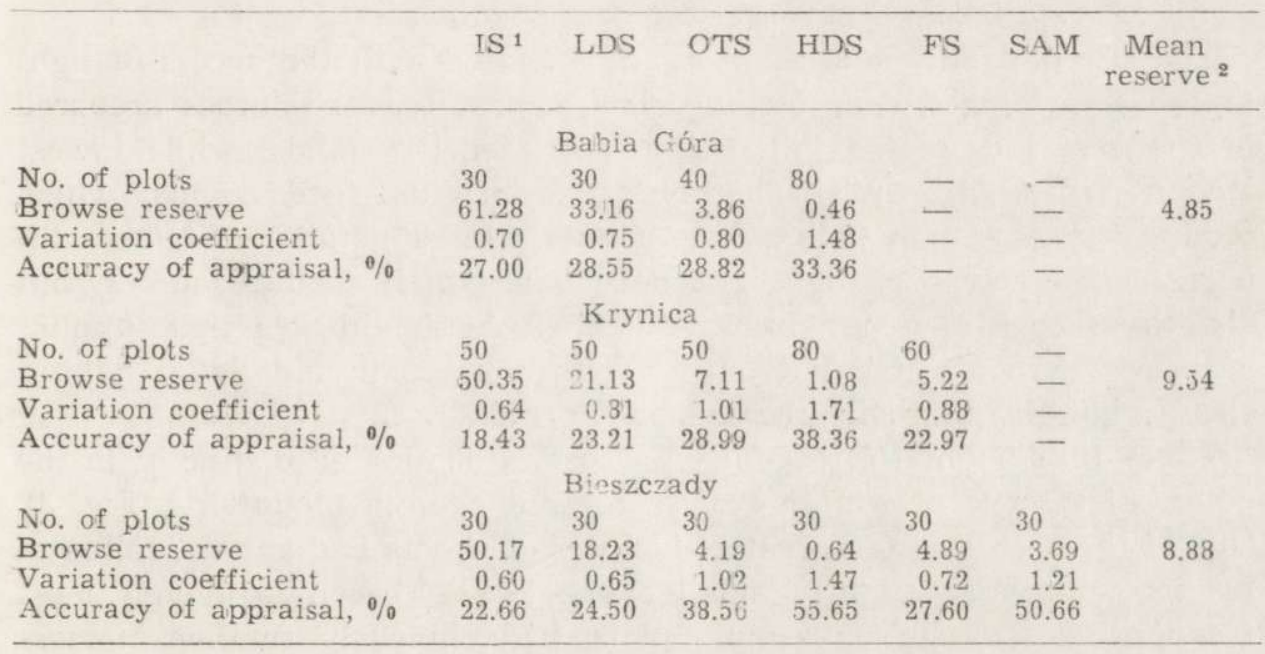

1 Symbols of classes: IS - initial stands; LDS - low density and regeneration stands; OTS - old timber stands; HDS - high density stands; FS - forecrop stands; SAM - shrubby alpine meadows.

2 Weighted mean depending upon the area proportion of the class identified.

Average biomass of browse approached $10 \mathrm{~g}$ of dry matter $/ \mathrm{m}^{2}$ in the Krynica forests and in Bieszczady and was almost by twice lower near Babia Góra. Browse biomass was most uniformly distributed in initial and loose density categories (variation coefficient smaller than 1), on contrary to stands with a high density and afforested meadows. One should stress (1) higher accuracy of estimate in stands with a greater 
biomass of browse and (2) influence of the number of plots upon the improvement of accuracy in browse resource estimates.

Statistical analysis indicaled that habitat categories studied differed significantly in respect to the biomass of winter browse. From among the three categories with the greatest biomass of shoots, comprised by initial stands, those in the Beskid Sądecki and Bieszczady did not revealed any significant differences, while those in the Babia Góra range had obviously greater biomass of shoots. Stands with a loose density and in regeneraition class were intermediate in respect to browse biomass between the initial category and remaining categories in forest habitat. Also in this cless of stands reserves on areas near ithe Babia Góra were significantly greater than in corresponding stands at Krynica and Bieszczady. Such a situation was caused by the higher proportion of coniferous species with a remarkably greater biomass of current growth shoots when compared to deciduous species in both most productive categories near the Babia Góra. All the remaining categories of habitat comprised a large group with small and failing to reveal any significant statistical differences biomass of 'browse.

The size of food resources is directly related with the access of light to the zone of red deer feeding. The richest food resources occurred in the best illuminated initial and loose density stands, while lowest amounts of food were in highly dense medium-aged stands, which occupied no less than $47 \%$ of the mountain forests studied. Stands with a restricted access of light not only have small food resources, but also this food is of minor nutritive value. One should note that supplies of browse are affected not only by its biomass in individual habitat classes, but also by their area proportion (Fig. 2).

Three fundamental forest-forming species dominated distinctly in the potential reserve of winter browse for red deer in mountains (Fig. 3). Out of them on average greatest biomass of shoots had spruce, followed by fir with only slightly smaller one, while beech, although most frequently occurring on sample plots, had obviously smaller biomass of shoots. Coniferous species are, thus, supplying by far greater volume of browse. Besides of the mentioned ones, another 6 species classed as commercially important occurred on sample plots; their joint proportion in twig biomass slightly exceeded $1 \%$. Altogether the species of the group discussed provided on average $85 \%$ of the potential deer browse, in which $3 / 4$ of biomass was provided by coniferous species and some $10 \%$ - by deciduous ones.

Species classed as less important from economic viewpoint provided from only $4 \%$ near Babia Góra to more than $20 \%$ in Bieszczady, on average $15 \%$ of the potential browse. Twigs of shrubs, particularly. 


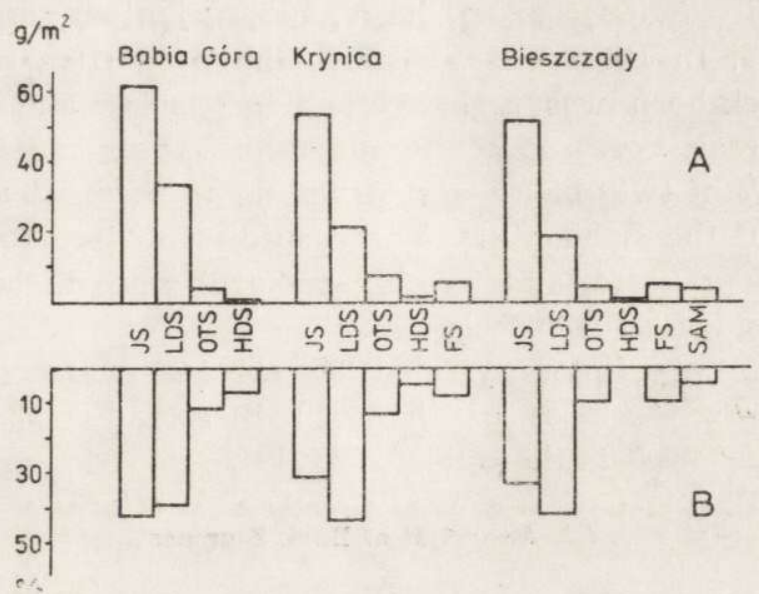

Fig. 2. Comparison of shoots' supply (A) and proportion of browse originating from it (B).

Symbols for categories of forest stands are the same as used in Table 1.

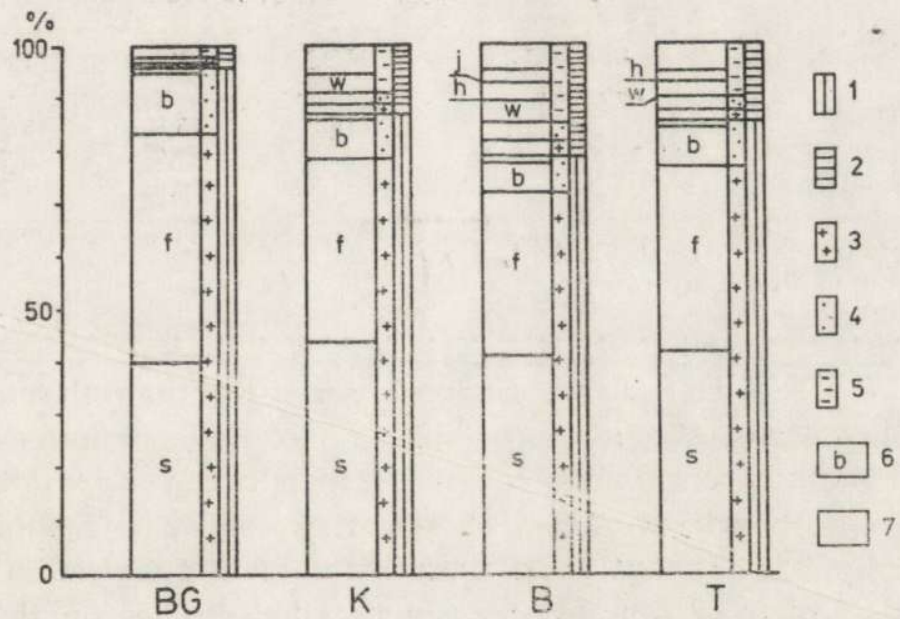

Fig. 3. Species composition of browse supplies in regions of Babia Góra (BG), Krynica (K), Bieszczady (B) and total (T).

Explanations:

1 - main forest forming and admixture species; 2 - forecrop, admixture light-seeded, and understorey species; 3 - coniferous trees; 4 - deciduous trees; 5 - shrubs; 6 - proportion of species with the given symbol; 7 - proportion of remaining species within the groups identified (1-5).

Symbols of species (to Figs. $3,5,6$ ):

$\mathrm{f}$ - Abies alba; $\mathrm{s}$ - Picea excelsa; b-Fagus silvatica; sm - Acer pseudoplatanus; a - Fraxinus excelsior; 1 - Tilia cordata; p - Pinus silvestris; w - Salix caprea and other willows; h - Corylus avellana; $\mathrm{j}$ - Juniperas communis; e - Sambucus racemosa and S. nigra; r - Sorbus aucuparia. 
willows (mainly Salix caprea), hazel, elder, juniper, and rowan tree prevailed here. In Bieszczady, besides, the proportion of bird cherry and alder buckthorn was high, while honeysuckle and rose occurred in all study areas. Forecrop coniferous species (pine and larch) supplied on average $2 \%$ of twig biomass, pine failing to occur at all in areas on the foothills of the Babia Góra. Three species of deciduous trees (grey alder, Betula verrucosa, and trembling aspen) were to be found in all areas and provided $2.4 \%$ of twigs.

Altogether sample plots yielded 35 species of trees and shri bs, providing browse - most of them in Bieszczady (28 spscies) and Krynica (26) and least in the Babia Góra (19).

\subsection{Appraisal of Bark Biomass}

As it results from Table 2 the grealtest possibilities of bark feedıng by red deer were in the category with a minimum reserve of browse in extremely dense medium-age stands. The calculated biomass of bark

Table 2

Biomass of bark available as red deer food in habitats studied in Krynica forests.

\begin{tabular}{|c|c|c|c|c|c|c|}
\hline & IS 1 & LDS & HDS & OTS & FS & Mean \\
\hline No. of plots & 15 & 15 & 15 & 15 & 15 & \\
\hline Bark biomass ${ }^{2}$ & 33.3 & 54.9 & 102.3 & 27.7 & 18.2 & $55.0^{3}$ \\
\hline Variation coefficient & 1.02 & 0.60 & 0.74 & 0.94 & 1.14 & 0.88 \\
\hline
\end{tabular}

1 Symbols of classes as in Table 1 ,

2 In grams of dry matter $/ \mathrm{m}^{2}$,

3 Weighted mean.

avallatue for red deer was considerably greater than that of twigs in all habitat classes, except of the initial one. Bark biomass was in the region of Krynica on average by more than 5 times greater than that of browse. Rather high values of variation coefficients evidence great variation in the distribution of bark biomass in field and the need of a greater number of sample areas in detailed studies on this resource.

Bark resources, similarly as in the case of browse, were dominated by three species - fir, beech, and spruce, which comprised $82 \%$ of all available bark. Apart of them in bark biomass participated another three "commercially important" and eight species with little economic importance.

\subsection{Characteristies of the Winter Diet of Red Deer}

The tracking after red deer revealed the consumption of shoots from 36 species of trees and shrubs by them: 20 species in the Babia Góra 
forests, 28 in Krynica, and 27 in Bieszczady. Shoots provided the major food of red deer in all the three study areas, comprising on average $64.0 \%$ of the entire diet measured (Fig. 4).

In the Babia Góra forests woody species, classed to commercially important constituted some $82 \%$ of shoots consumed, while the remainder was formed by shoots of shrubs and trees with a lesser economic importance (Fig. 5). The proportion of forest-forming species

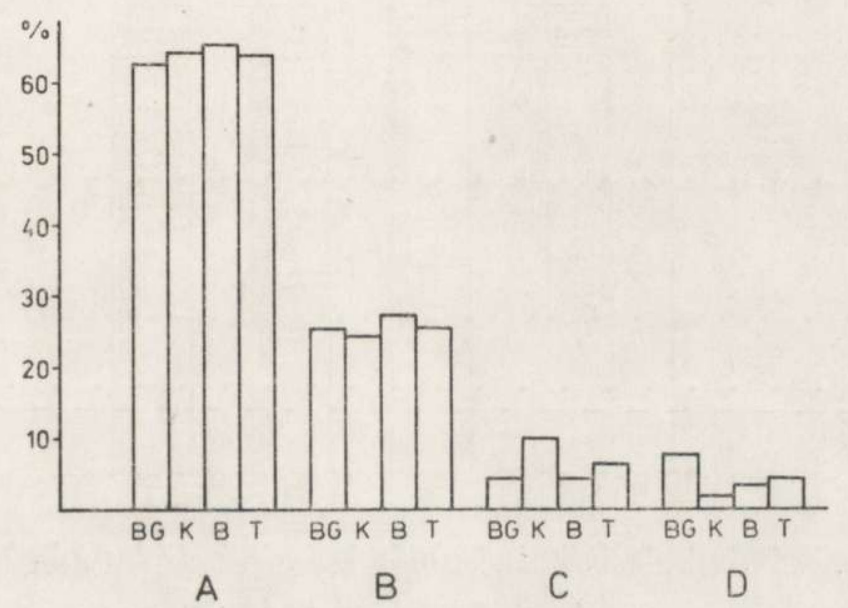

Fig. 4. Proportion of identified groups in the bulk of food consumed by red deer in the region of Babia Góra (BG), Krynica (K), Bieszczady (B) and total (T). A - twigs of trees and shrubs, B - bark, C - dwarf-shrubs, D - herbaceous plants.

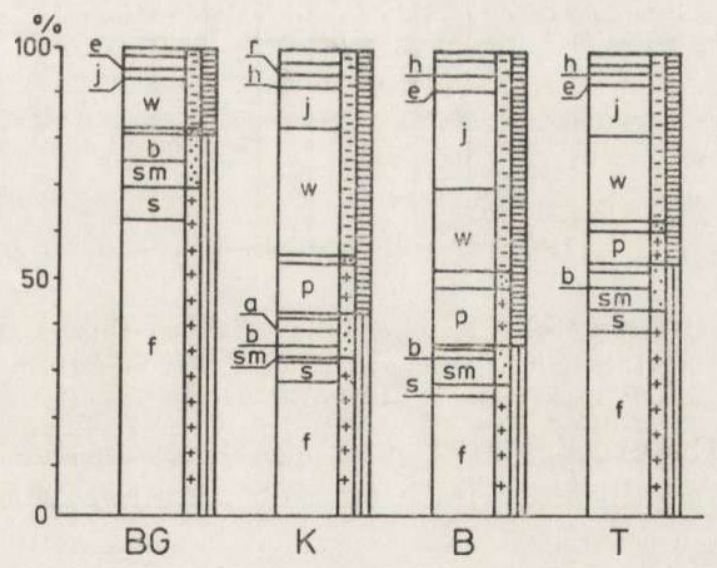

Fig. 5. Composition of browse consumed by red deer in the region of Babia Góra (BG), Krynica (K), Bieszczady (B) and in total (T).

Explanations - as in Fig. 3. 
in red deer diet was remarkably lower in the region of Krynica $(43 \%)$ and in Bieszczady $(36.5 \%)$. From this group the largest proportion in the bulk of shoots consumed had fir (altogether $39 \%$ of shoots), and successively spruce, sycamore maple (less than $5 \%$ each), beech $(3.5 \%)$, and ash $(1.5 \%)$. Sallow with a slight proportion of other willows $(19 \%)$, juniper $(10.5 \%)$, and pine $(8 \%)$ prevailed in the other group of woody

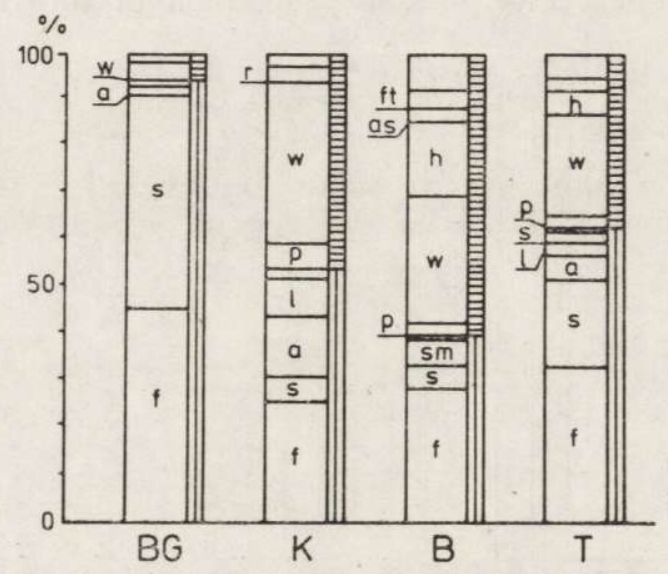

Fig. 6. Species composition of bark consumed by red deer tracked. Explanations - as in Fig. 3.

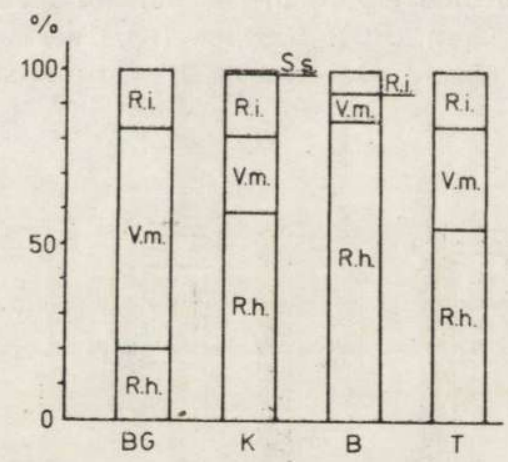

Fig. 7. Species composition of the bulk of dwarf-shrubs consumed.

V.m. - Vaccinium myrtillus; R.i. - Rubus idaeus; S.a. - Sarothamnus scoparius; R.h. - Rubus hirtus.

species (Fig. 5). The proportion of elder, hazel, rowan tree, and trembling aspen was still significant, while that of 23 other woody species negligible.

The bark of trees and shrubs constituted a significant portion of red deer diet - on average some $25 \%$ (Fig. 4). The animals consumed bark of altogether 27 species of trees and shrubs. In the three study areas 
jointly $63 \%$ of bark consumed by red deer came from forest-forming species - mainly fir $(33 \%)$, spruce $(19 \%)$, ash $(5 \%)$, limetree $(3 \%)$, and sycamore maple $(2.5 \%$ ) (Fig. 6). In the group of remaining species the greatest proportion had willows, first of all sallow $(22 \%)$, then hazel $(5 \%)$, pine (less than $3 \%$ ), rowan $(2.5 \%)$, trembling aspen $(1.5 \%)$, and thirteen other species.

Herb layer plants were consumed when snow cover did not exceed some $50 \mathrm{~cm}$, and most often in spots with snow blown away, during

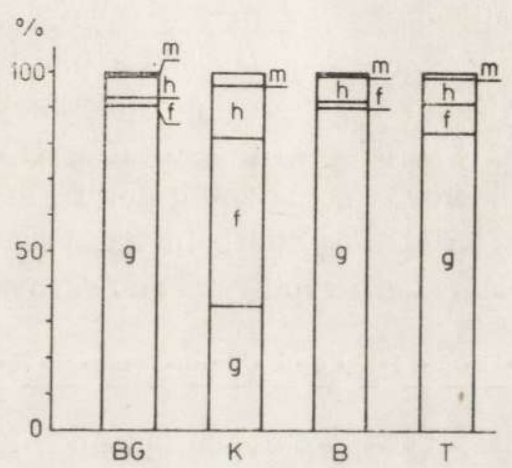

Fig. 8. Composition of herbaceous plants consumed by the red deer tracked.

$\mathrm{g}$ - grasses and other monocotyledons, f - ferns, h - dicotyledonous herbs, $\mathrm{m}$ - mosses

Table 3

Mean for the three study areas feeding by red deer within identified classes of forest habitat.

\begin{tabular}{lcccccccc}
\hline & IS ${ }^{1}$ & LDS & OTS & HDS & FS & SAM & NFA ${ }^{2}$ & Total \\
\hline $\begin{array}{l}\text { Length of } \\
\text { tracks, m }\end{array}$ & 14,090 & 25,540 & 22,480 & 55,950 & 16,350 & 4,340 & 63,300 & 145,080 \\
$\begin{array}{l}\text { Feeding } \\
\text { including: }\end{array}$ & 1113.6 & 1309.2 & 448.7 & 244.6 & 397.3 & 819.4 & 33.2 & 573.2 \\
$\begin{array}{l}\text { twigs } \\
\text { bark }\end{array}$ & 903.2 & 841.2 & 263.6 & 122.1 & 204.6 & 661.1 & 5.4 & 366.9 \\
$\begin{array}{l}\text { herbaceous } \\
\text { plants }\end{array}$ & 86.0 & 322.7 & 108.4 & 111.4 & 152.7 & 139.6 & - & 146.3 \\
\hline
\end{tabular}

1 Symbols of classes as in Table 1,

2 NFA - Non-forest areas (fields, glades, broad roads, etc.),

${ }^{3}$ In $\mathrm{g}$ of dry matter per $1 \mathrm{~km}$ of route tracked.

thaws at the end of winter, near streams, under windfallen trees, etc. There were not many such plants in red deer diet (up to several per cents). The proportion of dwarf- and half-shrubs amounted from more than $4 \%$ near Babia Góra and in Bieszczady to $10 \%$ ait Krynica. This food was constituted by three species as a rule (Fig. 7); blackberry, 
followed by whortleberry and raspberry. Herbaceous plants comprised from $1.5 \%$ of the winter diet of red deer at Krynica up to $7.5 \%$ near Babia Góra. Grasses were most important in this group (Fig. 8), proportion of dicotyledonous plants and ferns was visible, while than of mosses - negligible. Red deer diet comprised also casually consumed fruits, seed, and mushrooms, which constituted jointly only $0.1 \%$ of the diet.

The greatest amount of food has been taken by red deer in the category of stands with a lose density, abounding with understoreys and regeneration - on average some $1300 \mathrm{~g}$ per $1 \mathrm{~km}$ of track, as well as in natural and artificial regeneration and thickets (initial category) - some $1100 \mathrm{~g}$ per $1 \mathrm{~km}$ (Table 3 ). In the remaining habitat class s feeding intensity was lower - some $250 \mathrm{~g}$ per $1 \mathrm{~km}$ in dense middle-aged stands, $400 \mathrm{~g}$ in forecrop stands, $450 \mathrm{~g}$ in timber stands, and more than $800 \mathrm{~g}$ per $1 \mathrm{~km}$ in Bieszczady alpine meadows overgrown with shrubs.

\subsection{Food Preferences}

While compa:ing reserves to consumption of twigs of individual species of trees and shrubs (Fig. 9) one can note remarkable differences in their preferences. In the case of two species with the greatest reserve of browse, namely fir and spruce, a considerably lower preference towards the latter is obvious. Similarly the consumption of beech was proportionally lower than available reserve of its browse, but this discrepancy was not so great as in the case of spruce. On the other hand twigs of the main admixture species, the sycamore maple have been consumed in all study areas by far more frequently than would result from the average possibility of encountering them.

In the most preferred species, sought after by feeding animals among other plants, the quotient of their share in the food consumed and their proportion in the available reserve is obviously, even by several times greater than unity, while in less preferred species this quotient is smaller than unity and the smaller the less willingly the plant is consumed.

From among species with twigs most preferred by red deer willows and juniper, pine, and from cultivated species - sycamore maple take first position (Table 4). Here belong also ash, limetree, and trembling aspen, rowan tree, elder, and alder buckthorn. Joint proportion of the species mentioned in browse biomass amounted to $9.4 \%$, while their share in browse consumption - to $48.6 \%$. Preference for fir, twigs of which prevailed in the winter died of red deer, was lower than in the previous species, because its share in diet was more or less corresponding with their proportion in biomass. The preference of the two remaining 


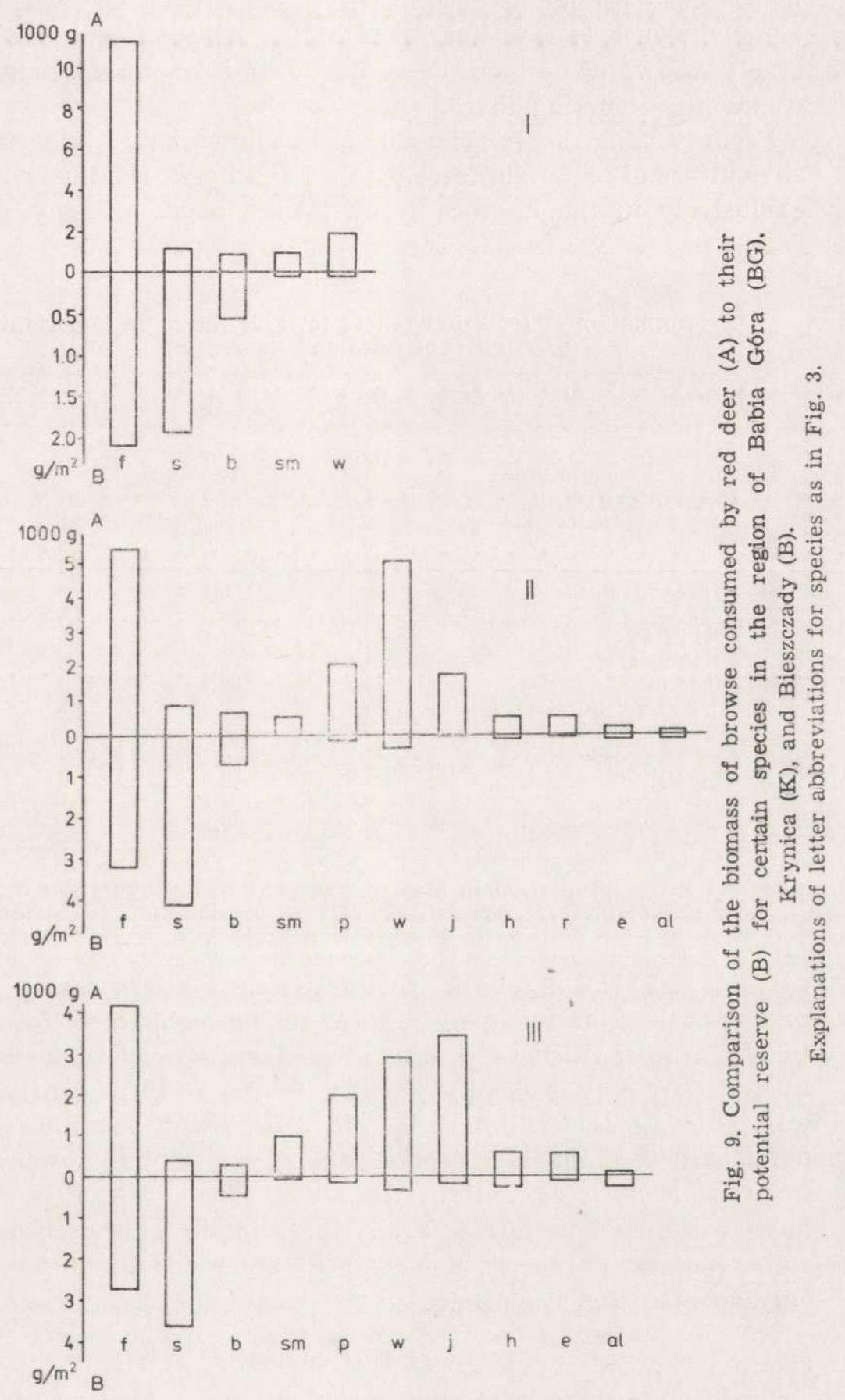


main forest-forming species, namely beech and spruce, was on the other hand obviously lower than that of fir. Alder, larch, and birch were rarely browsed by red deer in Carpathian forests among species commonly occurring there.

From among trees classed as commercially important in the silviculture of mountain forests, ashes and limetrees, the latter occurring exclusively in the Krynica forests, were most willingly debarked by

Table 4

Determination of food preferences towards the more important species of trees and shrubs.

\begin{tabular}{lrrrr}
\hline Species & BR $^{1}$ & BrC & BaC & PI \\
\hline Salix sp. & 3.1 & 18.6 & 21.8 & 6.0 \\
Juniperus communis & 1.3 & 10.5 & - & 8.1 \\
Pinus silvestris & 1.4 & 7.7 & 2.7 & 5.5 \\
Acer pseudoplatanus & 0.8 & 4.7 & 2.5 & 5.9 \\
Fraxinus excelsior & 0.3 & 1.6 & 5.2 & 5.3 \\
Tilia cordata & 0.1 & 0.3 & 2.9 & 3.0 \\
Populus tremula & 0.1 & 0.8 & 1.4 & 8.0 \\
Frangula alnus & 0.1 & 0.5 & 0.3 & 5.0 \\
Sorbus aucuparia & 0.7 & 1.6 & 2.4 & 2.3 \\
Sambucus sp. & 1.5 & 2.3 & 0.6 & 1.5 \\
Abies alba & 34.7 & 39.3 & 33.0 & 1.1 \\
Corylus avellana & 1.9 & 2.0 & 5.2 & 1.1 \\
Fagus silvatica & 7.7 & 3.5 & 0.1 & 0.4 \\
Picea excelsa & 41.7 & 4.7 & 18.9 & 0.1 \\
Alnus incana & 1.9 & 0.4 & 0.6 & 0.2 \\
Larix decidua & 0.6 & 0.1 & 0.1 & 0.2 \\
Betula verrucosa & 0.4 & 0.1 & - & 0.2 \\
\hline
\end{tabular}

$1 \mathrm{BR}$ - proportion in browse reserve, $\mathrm{BrC}$ - proportion in browse consumption, $\mathrm{BaC}$ - proportion in birk consumption, PI - preference index $(\mathrm{PI}=\mathrm{BrC}: \mathrm{BR})$.

red deer (Table 4). Bark peeling from sycamore maple was less preferred than browsing, while from among main forest-forming species the fir has been debarked mast often. Damage caused by bark peeling by red deer was decidedly greatest in the species mentioned. Spruce was debarked less willingly by red deer, while beech was practically not debarked. From among shrubs and remaining tree species, commonly occurring sallow, as well as trembling aspen, rowan tree, pine, and hazel were most preferred, similarly as in the case of browsing. Two, rather numerous species, namely grey alder and larch, were debarked only sporadically.

\section{DISCUSSION}

Results of studies on browse biomass in lowland forests were recapitulaited by $\mathrm{B}$ obe $\mathrm{k}$ et al. (1975), who indicated differentiation 
of browse reserves by far greater than that in the Fagetum carpaticum studied here. In mixed coniferous forest and in deciduous forest in the Białowieża Forest browse reserves were greater than in corresponding montane biotopes, while in the fresh coniferous forest, alderwood and deciduous forests in other regions of Poland this reserve was obviously smaller. One may state generally that browse reserve in the richest categories of mountain forest is relatively high and more diversified and abundant in species when compared to lowland forests. The biomass of browse in dense young plantations and thickets, particularly coniferous ones, in lowlands may remarkably exceed reserves in initial stands of the mountain forest.

Trees and shrubs, mainly in the form of browse, overwhelmingly prevailed in the diet of red deer tracked (about $90 \%$ ). Studies carried out by Dzięciołowski (1969) in lowlands indicated that shoots and bark of trees and shrubis comprised only $50 \%$ of the winter diet of red deer and the proportion of dwarf-shrubs amounted to almost $40 \%$. A h lén (1965b) found in southern Sweden that during winter red deer feed mainly in close-to-ground layer of vegetation, where they consume first of all grasses sought after beneath spreading crowns of big spruces. In deciduous forest, where snow crust was compact and frozen no less than $98 \%$ of red deer diet consisted of shoots and bark of woody plants. The data presented indicate how serious is the impact of snow cover upon the composition of the winter diet of red deer. One may assume that under conditionis of really snowy winters in mountains shoots and bark of trees and shrubs constitute the basic winter food of red deer.

Dominant proportion of fir in the species composition of plants consumed by red deer in the areas studied attracts attention. Fir comprised $1 / 3$ of the entire diet. Sallow had a very great proportion. In lowlands fir was replaced by pine, which in the three forest districts studied by Dzięiciolowski (1969) provided jointly half of the shoots and bark consumed, while in the Białowieża Forest (B o r o wski \& Koss a k, 1975) - also the hornbeam. The sallow was in the diet of red deer in Polish lowlands substituted most frequently by alder buckthorn. Verrucose birch had a high proportion in diet in the Białowieża Forest. It is also common in mountains and almost entirelv omitted by red deer. Willows, spruce, juniper, pine, hazel, and ash are species which provided an important portion of the winter diet of red deer both in mountains and in lowlands.

From among species debarked by red deer in mountain areas the biomass of bark from fir, sallow, spruce, ash, and hazel was greatest in the food consumed. These were, therefore, identical species as in 
lowlands (A huén, 1965a; Dzięgi elewski, 1973; B or owski \& $\mathrm{K}$ os s a k, 1975). Beech, almost entirely unpeeled in mountain forests and frequently seriously damaged in certain lowland locations, provided an exception. Larch, also almost unpeeled in mountains, was mentioned as regularly debarked in Sweden.

Feeding of red deer on woody species is related to the problem of damage done by these animals in forest management. The damage of main cultivated trees, as well as valuable admixture species is of greatest economic importance. Another group of species comprise shrubs and from among trees - light-seeded species (alder, birch, trembling aspen), pine and larch, which are only of periodical importance on the silviculture in study areas as forecrop species. Damage in plants of this group will not be, as a rule, of a seriouls economic importance.

Serious damage on preferred tree species has been, sometimes, encountered in the course of field work. Most severe damage has been done by red deer in plantings under the canopy of a stand, particularly when the areas were deprived of shrubby understorey species. On the other hand red deer feeding in natural regeneration appearing in abundance and with a differentiated age did not result, as a rule, in the destruction of regeneration. Damage was not of any greater extent in Bieszczady and in vicinity of Krynica, while it was by far more serious in foothills of the Babia Góra. From many years red deer inflict serious damage in the Babia Góra National Park and hinder the regeneration of fir. Such a situation may lead to the elimination of fir from forest species composition, as in Austria, where under the impact of red deer browsing the species retreated from $50 \%$ of its previous range during recent 5 decades (M a y e r, 1976).

It was evidenced in this paper that commercially important tree species constituted jointly to some $85 \%$ of the winter reserve of browse, but their proportion in died amounted to only $54 \%$. Species with negligible economic importance constituted $15 \%$ of reserve, but $46 \%$ of diet.

Damage caused by bark peeling was most severe in ash thickets (Krynica); fir was also frequently severely damaged and near Babia Góra - spruce. Almost 40\% of bark consumed came from species with a lesser economic importance, from among which numerous belong to highly preferred by the red deer.

Such species, as sallow, other willows, juniper, rowan tree, trembling aspen, not only provide favourite food of red deer during winter, but play also an important part of buffer plants distracting those animals from browsing on commercially important species. In order to reduce the danger of damage one should: (1) encourage those species in lower 
storeys of a stand, (2) leave them in natural and artificial regeneration, and (3) consider possibilities of their simultaneous introduction with species of destination under the canopy of reconstructed stands.

\section{REFERENCES}

1. A h lén I., 1965a: Studies on the red deer, Cervus elaphus L., in Skandinavia. III. Ecological investigations. Viltrevy, 3: 177-376.

2. Ahlén I., 1965b: A comparison between the winter feeding behaviour of the red deer and moose. I.U.G.B. Transactions of the VIth Congress, Bournemonth, October 1963.

3. A hlén I., 1975: Winter habitats of moose and deer in relation to land use in Scandinavia. Viltrevy, 9: 45-192.

4. Bobek B., Borowski S. \& Dzięciołowski R., 1975: Browse supply in various forest ecosystems. Polish ecol. Stud., 1: 17-32.

5. Bobek B., Perzanowski K., Sajdak G. \& Szulakowska G., 1974: Seasonal changes in quality and quantity of deer browse in a deciduous forest. Proc. XIth Int. Congress of Game Biologists, Stockholm 1973.

6. Borowski S. \& Kossak S., 1975: The food habits of deer in the Białowieża Primeval Forest. Acta theriol., 20: 463-505.

7. De Vos A. \& Mosby H. S., 1969: Habitat analysis and evaluation. [In: "Wildlife management techniques« Ed. R. H. Giles]. The Wildlife Society: 135-172. Washington.

8. Dzięciolowski R., 1969: The quantity, quality and seasonal variation of food resources available to red deer in various environmental conditions of forest management. Forest Res. Inst.: 1-295. Warsaw.

9. Dzięciolowski R., 1974: Ekologiczne podstawy hodowli jeleni w lasach. Wiad. ekol., 20: 21-46.

10. Dzięciolowski R., Kossak S., Borowski S. \& Morow K., 1975: Diets of big herbivorous mammals. Polish ecol. Stud., 1: 33-50.

11. Dzięgielewski S., 1973: Jeleń. Państw. Wyd. Roln. i Leśn.: 1-344. Warszawa.

12. Klein D. R., 1965: Ecology of deer range in Alaska. Ecol. Monographs, 35: $259-284$.

13. M a y er H., 1976: Zur Wiederherstellung und Erhaltung eines Ókologischen Gleichgewichtes zwischen Wald und Wild in Gebirge. XI IUFRO World Congress, Group 1: 23-34.

14. Oktaba W., 1977: Elementy statystyki matematycznej i metodyka doświadczalnictwa. Państw. Wyd. Nauk.: 1-310. Warszawa.

15. Shafer E. L., Jr., 1965: Deer browsing of hardwoods in the Northeast. U.S. For. Serv. Research Paper, NE-33.

Accepted, February 11, 1980. 
Grzegorz JAMROZY

\section{ZIMOWE ZASOBY ZERU I PREFERENCJE POKARMOWE JELENI W LASACH} KARPACKICH

\section{Streszczenie}

W pracy tej przedstawione zostały wyniki: (1) pomiarów zimowych zasobów pokarmowych jeleni, głównie żeru pędowego a także nieskorkowaciałej kory drzew i krzewów, oraz (2) badań zimowej diety jeleni. Prace terenowe prowadzono w lasach dolnoreglowych $w$ trzech terenach badawczych położonych w zachodniej, środkowej i wschodniej części polskich Karpat (Ryc. 1).

Spośród kategorii biotopu leśnego, wydzielonych w ramach zespołu Fagetum carpaticum, największe zasoby żeru pędowego znajdowaly się w drzewostanach inicjalnych $\left(50-61 \mathrm{~g}\right.$ suchej masy na $\left.1 \mathrm{~m}^{2}\right)$ oraz drzewostanach o luźnym zwarciu i w klasie odnowienia (18-33 g) a najmniejsze $w$ drzewostanach silnie zwartych $(0,5-1,1$ g) (Tabela 1). Biomasa kory mogącej stanowić żer jeleni, pomierzona w rejonie Krynicy, była przeciętnie 5-krotnie wyższa od zapasu żeru pędowego (Tabela 2). Zarówno w biomasie pędów jak i kory dominowaly trzy gatunki lasotwórcze: jodla (przeciętnie $35 \%$ zapasu pędów i $32 \%$ kory), świerk $(42 \%$ pędów i $20 \%$ kory) i buk ( $8 \%$ pędów i $30 \%$ kory) a z krzewów iwa (po około $3 \%$ pędów i kory); w sumie zapas pędów tworzyły 32 gatunki a kory 14 gatunków.

Podstawą zimowej diety jeleni byly drzewa i krzewy (okolo $90 \%$ pomierzonej diety), przede wszystkim w postaci żeru pędowego, a także spałowanej kory (Ryc. 4). Występująca $\mathrm{z}$ reguly w górach gruba pokrywa śnieżna wylączyła w dużym stopniu z diety roślinność przyziemną - krzewniki oraz zielne rośliny runa. Wśród 36 zgryzanych i 27 spałowanych gatunków dominujący był udział jodly i bardzo wysoki iwy (Ryc. 5 i 6). Dla żerowanych gatunków określono wskaźniki preferencji pokarmowej (Tabela 4). Do gatunków o najwyższej preferencji pędów należały: wierzby, jałowiec, sosna, jawor, jesion i szereg gatunków podszytowych, a najchętniej spotykane byly: jesion, iwa, jarzębina, osika, sosna i kilka innych. Należy zaznaczyć, że krzewy były najczęściej bardziej preferowane niż hodowane gatunki drzew, co określa ich rolę jako gatunków buforowych, zmniejszających niebezpieczeństwo szkód wyrządzanych przez jelenie. 